„Kwartalnik Filmowy” nr 113 (2021)

ISSN: 0452-9502 (Print) ISSN: 2719-2725 (Online)

https://doi.org/10.36744/kf.681

(c) Creative Commons BY-NC-ND 4.0

\title{
Milosz Stelmach
}

Uniwersytet Jagielloński

https://orcid.org/0000-0003-4004-7121

\section{Drugi przelom dźwiękowy? Magnetofon Nagra i przemiany filmowego dźwięku w epoce postklasycznej}

\author{
Słowa kluczowe: \\ Nagra; \\ Stefan Kudelski; \\ dźwięk filmowy; \\ technika filmowa; \\ historia filmu; \\ Nowe Hollywood
}

\begin{abstract}
Abstrakt
Celem autora jest przybliżenie wpływu, jaki wywarł na kinematografię Stefan Kudelski i stworzona przez niego marka magnetofonów Nagra. Zwłaszcza skonstruowana pod koniec lat 50. Nagra III stała się niezwykle popularna wśród filmowców (wraz z innymi przełomowymi wynalazkami tego okresu), przyczyniając się do powstania nowego typu kina dokumentalnego, a także wpływając na metody produkcji fabularnej. Magnetofony marki Nagra na blisko trzy dekady stały się branżowym standardem, współtworzac takie ruchy jak francuska Nowa Fala czy Nowe Hollywood i tym samym biorąc znaczący udział w kształtowaniu się estetyki kina postklasycznego, wprowadzającego nowy rodzaj filmowego realizmu, a także znacznie zwiększając swobodę w operowaniu dźwiękiem. Ten istotny epizod z historii techniki filmowej stanowi pretekst ukazania w jaki sposób postęp techniczny może stanowić przyczynek do przemian organizacji produkcji, praktyk branżowych, a także rozwiązań stricte artystycznych.
\end{abstract}


Dwie tendencje - mniejsze zainteresowanie technologią filmową oraz podrzędna rola dźwięku w badaniach filmoznawczych - sprawiają że w znikomym stopniu zwracamy uwagę na to, jak powstaje ścieżka dźwiękowa dzieła filmowego i w jaki sposób zmieniały się techniki rejestracji w tym zakresie. Zwłaszcza jej niemuzyczna część, czyli dialogi, efekty dźwiękowe i dźwięki tła, często jest traktowana jako oczywisty komponent szeroko pojętej formuły filmu dźwiękowego istotny znaczeniowo i niejednokrotnie interpretowany na poziomie tekstualnym, ale niewymagający dodatkowych dociekań odnoszących się do realizacji. Tymczasem historia kina, nie tylko ta produkcyjna czy technologiczna, ale również stricte estetyczna, wymaga uwzględnienia także tego ostatniego aspektu. Jak już zauważał w latach 80. Rick Altman, do opisu stylu wizualnego wypracowaliśmy dość rozbudowany, precyzyjny język i zaakceptowaliśmy fakt, że aby pojąć wizualną stronę filmu, musimy uwzględnić rozmaite aspekty techniczne: ustawienie i ruchy kamery, dobór przesłony oraz ogniskowej obiektywu czy rodzaj zastosowanej taśmy. Jednocześnie podobne parametry związane z rejestracją dźwięku - typ i sposób umiejscowienia mikrofonów, wykorzystywany nośnik czy sprzęt służący do obróbki i montażu - pozostają domeną wąskiej grupy specjalistów ${ }^{1}$. Wydaje się, że przez ostatnie 35 lat, które upłynęły od czasu postawienia tej diagnozy, niewiele się zmieniło.

Tymczasem to, jak brzmią filmy, zależy oczywiście od wielu decyzji artystycznych podejmowanych przez twórców w toku produkcji , owe decyzje są jednak uwarunkowane dostępnymi możliwościami technicznymi. Te zaś, w całej historii kina, nieustannie się rozwijały - od drugiej połowy lat 20., czyli przełomu dźwiękowego (a do pewnego stopnia także wcześniej²), technologia służąca rejestracji i obróbce dźwięku zmieniała się ustawicznie, a wraz z nią ewoluowały obowiązujące standardy branżowe oraz alternatywy względem nich. Niektóre dominowały przez lata, inne pojawiały się na krótko lub nawet nie wychodziły poza fazę eksperymentów, wszystkie jednak stworzyły historię medium, w znaczący i nieprzypadkowy sposób zazębiając się z innymi, ważniejszymi przełomami i punktami zwrotnymi. Choć często tego nie dostrzegamy (a raczej nie słyszymy), rewolucyjny charakter i powodzenie takich nurtów jak amerykańskie kino bezpośrednie czy Nowe Hollywood zależały także od nowych możliwości technicznej rejestracji dźwięku.

W niniejszym tekście chciałbym się przyjrzeć jednemu z najważniejszych epizodów w historii realizacji dźwięku filmowego, szczególnie istotnemu z punktu widzenia rodzimej refleksji, gdyż będącego efektem prac polskiego konstruktora Stefana Kudelskiego. Choć jego najważniejszy wynalazek - magnetofon Nagra III - ponad 60 lat temu zrewolucjonizował sposób realizacji filmów, a on sam przeszedł do historii jako pierwszy pochodzący z Polski laureat dwóch Oscarów, jego nazwisko nawet filmoznawcom pozostaje praktycznie nieznane. Tymczasem sprzęt przez niego opracowany, umożliwiający nagrywanie dźwięku bezpośrednio w plenerze, dzięki swojej niezawodności i poręczności stał się na blisko cztery dekady branżowym standardem i podstawowym elementem wyposażenia większości ekip filmowych i telewizyjnych na całym świecie, odciskając piętno na powojennym kinie, radiu i telewizji. Główną tezą artykułu jest zatem przekonanie, że magnetofon Nagra (i pokrewne mu wynalazki) nie tylko zrewolucjonizował techniczny sposób rejestracji dźwięku, ale także pomógł ukształtować estetykę kina postklasycznego. 
Stało się tak, mimo że ten wynalazek nie został stworzony z myślą o filmie. Stefan Kudelski nigdy nie miał bezpośredniego doświadczenia z tą branżą - był po prostu znakomitym konstruktorem, który swoje życie poświęcił udoskonalaniu sprzętu do rejestracji dźwięku. Urodzony w 1929 r. w Warszawie, uciekł z kraju wraz z rodzicami w czasie II wojny światowej - najpierw do Francji, potem do Szwajcarii. Tam też pozostali po wojnie, gdzie Kudelski studiował na politechnice w Lozannie, równolegle konstruując w domowej pracowni pierwsze wynalazki. Impulsem do stworzenia niewielkiego przenośnego aparatu do nagrywania dźwięku na taśmie magnetycznej był widok ekipy Radia Genewa realizującej w mieście reportaż. Rejestracja wymagała sprzętu pokaźnych rozmiarów, w tym grawera dysków, na których zapisywano dźwięk, a którego ciężar, gabaryty i zawodność utrudniały pracę w terenie lub trudnych warunkach ${ }^{3}$. Nowe urządzenie miało to zmienić, być proste w konstrukcji i obsłudze, niezależne od zasilania zewnętrznego (pierwsze modele były nakręcane, późniejsze działały na baterie), a przy tym lekkie i odporne na wstrząsy oraz warunki pogodowe.

Kudelski opracował prototyp magnetofonu Nagra już w 1951 r., w wieku zaledwie 22 lat. Być może od początku przeczuwał jego późniejszą karierę międzynarodową specjalnie wybierając nazwę jednocześnie swojską i kosmopolityczną. Jak sam wspomina: Długo zastanawiałem się, jakie imię nadać mojemu dziełu, nie chcac dawać mu własnego nazwiska. Wybrałem egzotycznie brzmiace, w moim odczuciu, słowo pochodzace od polskiego czasownika "nagrywać". Jak się po wielu latach okazało, "Nagra" rzeczywiście brzmiało na tyle egzotycznie, że Biały Dom kupował ja w Japonii w przekonaniu, że jest to nazwa japońska $a^{4}$ Na pierwsze międzynarodowe sukcesy nie trzeba było zresztą długo czekać - dzięki mobilności, a także odporności na niskie temperatury Nagra została zabrana na organizowaną w 1952 r. wyprawę na Mount Everest (szczyt wówczas wciąż jeszcze niezdobyty) przez szwajcarskiego alpinistę Raymonda Lamberta oraz Radio Genewa. W tym samym roku Kudelski otrzymał także nagrodę na odbywającym się akurat w Lozannie Pierwszym Międzynarodowym Konkursie Nagrywania dla Amatorów.

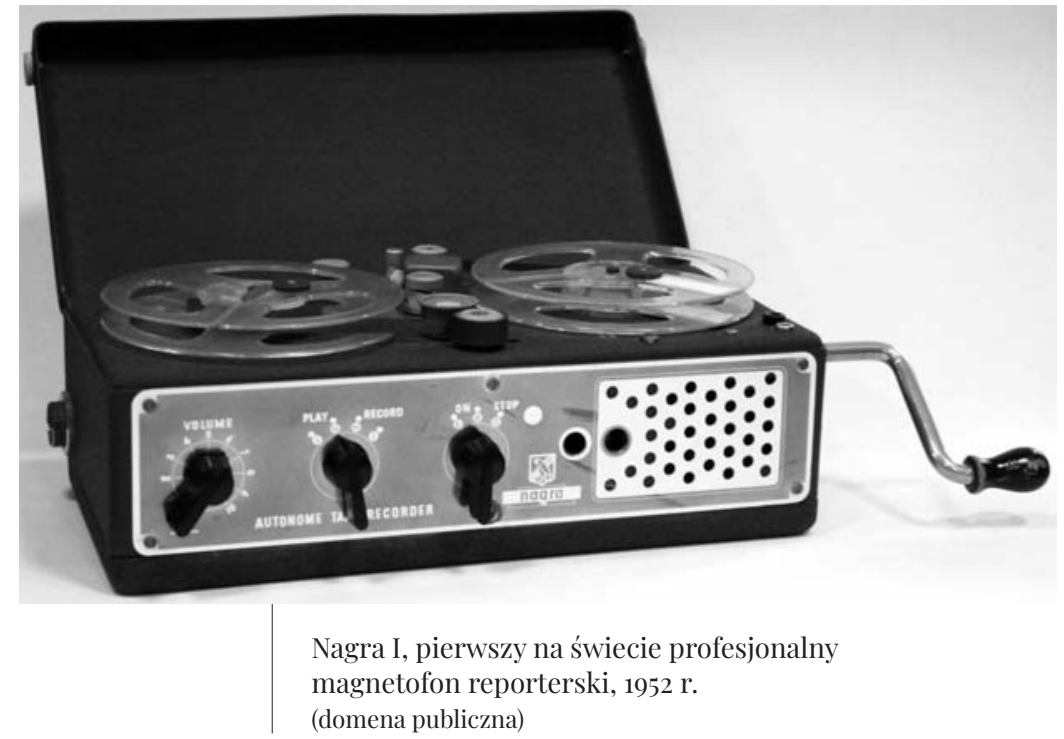


Od tej pory Nagra ciągle ewoluowała - jej kolejne generacje i modele były oznaczane rzymskimi cyframi lub skrótami literowymi, często nieco się różniły parametrami, a w związku z tym także przeznaczeniem. W sumie pod tą nazwą powstało ponad dwadzieścia różnych urządzeń, a ostatnia wersja to cyfrowa Nagra Seven z 2013 r. W historii kina najbardziej zapisał się kultowy model Nagra III, wprowadzony na rynek w 1958 r., ale znaczną sławę zyskała też miniaturowa, ważąca niespełna pół kilograma i produkowana w kilku wariantach Nagra SN (od série noir) o wymiarach ok. $15 \mathrm{~cm}$ na $10 \mathrm{~cm}$ na $2,5 \mathrm{~cm}$, skonstruowana na użytek amerykańskich służb specjalnych, ale wykorzystywana przez agencje wywiadowcze na całym świecie. Od tej pory wynalazek Kudelskiego odgrywał kluczową rolę w rejestracji materiałów dla radia i telewizji. Pojawiał się zwłaszcza tam, gdzie warunki realizacyjne były szczególnie trudne oraz nieprzewidywalne - w 1960 r. towarzyszył oceanografowi Jacques'owi Piccardowi w wyprawie na dno Rowu Mariańskiego, a w 1969 r. wraz z Nealem Armstrongiem wylądował na Księżycu. Bez Nagry nie powstałyby także liczne materiały korespondentów wojennych z Wietnamu. Jeszcze wcześniej włoska telewizja RAI zamówiła aż sto egzemplarzy, relacjonując przy ich wykorzystaniu olimpiadę w Rzymie w 1960 r. Mniej więcej w tym samym czasie wynalazek Polaka zaczął podbijać świat filmu, zmieniając techniczne warunki rejestracji dźwięku, a także współkształtując estetykę rodzącego się właśnie kina postklasycznego.

\section{Realizm i niezawodnośćc}

Żeby docenić rolę, jaką w historii kina odegrała Nagra (i kilka innych, podobnych jej wynalazków), musimy krótko zrekonstruować techniczne i estetyczne normy panujące przed jej powstaniem. Oczywiście technologie i praktyki związane z rejestracją i obróbką dźwięku zmieniały się nieustannie, a szczególnie istotne było przejście w latach 50 . z zapisu optycznego na magnetyczny ${ }^{5}$, ale podstawowe zasady, wyznaczające sposób funkcjonowania dźwięku w kinie hollywoodzkim, pozostawały stabilne przez cały okres klasyczny i opierały się w głównej mierze na dźwięku realizowanym w kontrolowanych warunkach studyjnych. W przypadku produkcji powstających w odpowiednio wyposażonych i przystosowanych do tego celu dekoracjach ustawionych w halach zdjęciowych dialogi były przeważnie nagrywane równocześnie z obrazem i uzupełniane o powstające niezależnie pozostałe elementy ścieżki dźwiękowej, w tym niemal wszystkie dźwięki otoczenia (kroki, trzaśnięcia drzwiami, szum uliczny, wystrzały itd.). Pochodziły one przeważnie z zasobnych bibliotek dźwięku dużych wytwórni lub były preparowane przez imitatorów dźwięku na potrzeby konkretnej produkcji. Z różnych powodów w niektórych przypadkach było także pożądane osobne dogranie części lub nawet wszystkich dialogów w formie tzw. postsynchronów (w języku angielskim znanych jako looping albo $A D R$ - automated dialogue replacement), wykonywanych przez aktora odgrywającego daną postać lub jego zastępcę. Trudności związane z procesem tworzenia efektów dźwiękowych na etapie postprodukcji sportretowali jeszcze w epoce kina klasycznego w humorystyczny sposób Stanley Donen oraz Gene Kelly w Deszczowej piosence (Singin' in the Rain, 1952), zaś współcześnie, w mroczniejszym wydaniu, wrócił do nich Peter Strickland w Berberian Sound Studio (2013). 
W przypadku zdjęć plenerowych, ze względu na gabaryty sprzętu, jego energochłonność, a także czułość na zakłócenia i niemożność wyizolowania pożądanych odgłosów, w praktyce w grę wchodziła wyłącznie druga ze wspomnianych możliwości, czyli realizacja całej ścieżki dźwiękowej w postprodukcji, niezależnie od obrazu. Stąd w latach 50., kiedy jednym z wiodących trendów kina hollywoodzkiego stały się osadzone w autentycznych lokacjach superprodukcje historyczne, skłonność do realizacji zdjęć plenerowych paradoksalnie oznaczała, że jeszcze większa część pracy nad dźwiękiem została przeniesiona na etap postprodukcjí. Ta zależność okaże się szczególnie istotna dla rozważań nad filmowym realizmem, który w refleksji teoretycznej i krytycznej jest często łączony z praktyką realizacji zdjęć w prawdziwych lokacjach, przy pominięciu faktu, że „autentyczność” obrazu jest niejednokrotnie okupiona „sztucznością” dźwięku. Oczywiście nie było to zmartwienie wielkich wytwórni amerykańskich, dla których kontrola nad poszczególnymi aspektami produkcji była znacznie ważniejsza niż jakkolwiek pojęta wierność względem rzeczywistości, o czym świadczyły choćby wieloletnie praktyki w zakresie realizacji zdjęć w studiu, przy użyciu umownej scenografii, tylnej projekcji udającej plenery itd. Ta skonwencjonalizowana estetyka kina hollywoodzkiego w organiczny sposób, niejako komplementarnie względem obrazu, inkorporowała sztuczność wyizolowanych w studiu, postsynchronicznych dźwięków, współtworzących umowność świata przedstawionego.

Jednak Problem autentyczności powraca, jeśli przyjrzymy się twórczości reżyserów pracujących w obrębie odmiennych tradycji bądź poszukujących narzędzi dla poetyk alternatywnych względem modelu hollywoodzkiego. Przykładowo, często powtarzana legenda filmoznawcza głosi, że źródłem oryginalności włoskiego neorealizmu było wyjście filmowców na ulice powojennego Rzymu, powodowane chęcią rejestrowania otaczającej rzeczywistości. Niezależnie od olbrzymiego uproszczenia, a momentami wręcz przekłamania ukrytego za tą tezą (zwróćmy uwagę choćby na fakt, że wszystkie „wnętrza” w paradygmatycznych dla nurtu Złodziejach rowerów /Ladri di biciclette, reż. Vittorio de Sica, 1948/ zostały zrealizowane w studiu, zaś „plenery” były odgrywane na zamkniętej na potrzeby filmu ulicy z wykorzystaniem sztucznego oświetlenia, deszczu itp. oraz starannej choreografii zatrudnionych statystów), dodać należy, że na ulice mogła ewentualnie wyjść kamera - mikrofon musiał pozostać w studiu. W prawie wszystkich filmach nurtu dialogi były więc nagrywane w formie postsynchronów, przez co nierzadko naturszczycy (kolejny punkt chluby włoskiego neorealizmu) byli zastępowani w warstwie audialnej przez profesjonalnych aktorów, co spotkało na przykład Lamberta Maggioraniego, odtwórcę głównej roli we wspomnianych Złodziejach rowerów. David Bordwell i Kristin Thompson zasugerowali nawet, że duże doświadczenie w realizacji dubbingu do filmów zagranicznych, dające pewność co do wysokiej jakości postsynchronizowanych dialogów, było jednym z elementów skłaniających włoskich twórców do pracy poza studiem7

Nie oznacza to, że w kinie klasycznym nie powstawały filmy z plenerowym dźwiękiem synchronicznym, jednak stanowiły one rzadkość - takim wyjątkiem był np. Toni (1934) Jeana Renoira czy Ziemia drży (La terra trema, 1948) Luchina Viscontiego. Większość słynnych filmów i nurtów chwalonych za zwrócenie się ku zastanej rzeczywistości i temu, co oferuje miasto, codzienność czy ulica, korzystała z dźwięku dogrywanego w studiu - tak było nie tylko w przypadku wspomnia- 
nego wyżej włoskiego neorealizmu, ale też brytyjskich dokumentów spod znaku Free Cinema i późniejszych fabuł „młodych gniewnych” czy fundamentalnych dla Nowej Fali 400 batów (Les quatre cents coups, reż. François Truffaut, 1959) i Do utraty tchu (À bout de souffle, reż. Jean-Luc Godard, 1960). O tym, że nagrywanie dźwięku na planie nie było łatwe, przekonał się Jacques Rozier, który zrealizował w ten sposób debiutancki film Adieu Philippine (1961) tylko po to, aby później odrzucić całą „setkową" ścieżkę dźwiękową jako wadliwą i dograć ją raz jeszcze w studiu ${ }^{8}$.

Jednocześnie owa narastająca na przełomie lat 50. i 60. tendencja do realizacji zdjęć w zastanych lokacjach jedynie początkowo nie obejmowała kwestii dźwięku. Chęć wzmocnienia wrażenia autentyzmu, a także np. eksperymentowania z dialogami improwizowanymi czy wplecenia w tkankę filmu sekwencji paradokumentalnych, niemożliwych do odtworzenia w studiu, skłaniała twórców do poszukiwania adekwatnych rozwiązań technicznych. Pierwsze impulsy i rozwiązania możliwe do powszechnego wprowadzenia powstały na gruncie kina dokumentalnego, w przypadku którego wierność względem zastanej rzeczywistości była szczególnie istotna, bo dotykała kwestii wiarygodności i tożsamości dokumentu jako rodzaju filmowego. To zatem jego twórcy (podobnie jak filmowcy pracujący dla telewizji realizującej często pokrewne cele) podeszli z entuzjazmem do pojawiających się wówczas nowinek technologicznych. Podkreślając kluczową rolę przenośnego, zsynchronizowanego z kamerą magnetofonu w powstawaniu nowego typu dokumentalistyki spod znaku direct cinema czy cinéma-vérité, Mirosław Przylipiak pisze nawet o panującym w tym okresie swoistym fetyszyzmie technologicznym, stwierdzając, że bodaj nigdy w historii kinematografii szczegóty techniczne nie wzbudzały takiego zainteresowania ${ }^{9}$. W monografii amerykańskiego kina bezpośredniego badacz wskazuje różne przejawy tego zainteresowania, skutkującego często na poły chałupnicznymi metodami pracy - twórcy własnoręcznie usprawniali i przerabiali dostępny sprzęt, a także poszukiwali niestandardowych rozwiązań technologicznych. Możliwość dyskretniejszego i bardziej elastycznego niż do tej pory nagrywania na planie wypowiedzi protagonistów oraz dźwięków ich otoczenia, a także podążania za postaciami w trakcie zdjęć stanowiła podstawę kina dokumentalnego tamtego okresu.

Z czasem jednak eksperymenty z dźwiękiem zgrywanym synchronicznie podczas pracy na planie przeniknęły z twórczości dokumentalnej na obszar wysokobudżetowej produkcji fabularnej, zarówno europejskiej, jak i hollywoodzkiej. O przełomowej roli urządzenia Kudelskiego zaświadczają opinie praktyków, w tym te pochodzące z tomu Vincenta LoBrutto, zawierającego wywiady z dźwiękowcami. Na temat Nagry wypowiada się tam m.in. Jack Solomon, sześciokrotnie nominowany do Oscara i nagrodzony statuetką Akademii za najlepszy dźwięk do filmu Hello, Dolly! (reż. Gene Kelly, 1969). Ten weteran kina amerykańskiego, który w latach 1953-1998 pracował przy ponad stu produkcjach, przyznał: Nagra III zrewolucjonizowała branżę. Kiedyś jeździliśmy na lokację z dziesięciotonowa ciężarówka petna sprzętu do nagrywania. Teraz wystarczy mała furgonetka lub van. W tym samym czasie, kiedy pojawiła się Nagra, zaczęty powstawać także lżejsze odpowiedniki pozostałych części wyposażenia ${ }^{10}$.

Według samego Kudelskiego pierwszym filmem fabularnym zrealizowanym przy użyciu Nagry był Czarny Orfeusz (Orfeu Negro, 1959) Marcela Camusa, który, choć bardzo wystylizowany i baśniowy, powstawał częściowo w zastanych 
lokacjach brazylijskich faweli przy udziale naturszczyków. Wprawdzie muzyka brazylijska odgrywająca w filmie istotną rolę została nagrana w studiu, ale już niektóre dialogi i śpiew bohatera zostały zarejestrowane na planie. Żywię do niego wielki sentyment. Po pierwsze byt to debiut kinowy mojej Nagry, a po drugie jest to film pełen poezji11 - wspominał po latach Kudelski. Jego sympatia do filmu Camusa nie była odosobniona - zdobył on m.in. Złotą Palmę w Cannes i Oscara za najlepszy film nieanglojęzyczny.

Tymczasem Nagra nie była ani jedynym, ani nawet pierwszym dostępnym wówczas dla filmowców sprzętem, warto więc wspomnieć przynajmniej o kilku najważniejszych alternatywach. Pierwszą z nich był kanadyjski system Sprocketape, stworzony już w 1955 r., dzięki któremu dźwięk synchroniczny z planu pojawił się w zrealizowanym dla tamtejszej telewizji cyklu Ukryta kamera (Candid Eye, reż. Terence Macartney-Filgate, 1958), a także w kojarzonym z nurtem direct cinema dokumencie Lonely Boy (reż. Wolf Koenig, Roman Kroitor, 1962) o gwieździe piosenki Paulu Ance. Z kolei w Stanach Zjednoczonych pojawił się w tym czasie system Auricon Filmagnetic, który stanowił niespotykane połączenie kamery $16 \mathrm{~mm}$ i urządzenia do nagrywania dźwięku. Został on wykorzystany podczas pracy nad przełomowym dla kina bezpośredniego filmem Primary (reż. Robert Drew, 1960). Ze względu na niższą cenę wiele amatorskich i półamatorskich ekip telewizyjnych korzystało z francuskiego magnetofonu Perfectone, wprowadzonego do użytku w 1958 r. Znaczącym graczem na rynku był (także szwajcarski) Stellavox, mniejszy i lżejszy od konkurencyjnych urządzeń, ale za to znacznie droższy.

Jak na tym tle prezentowała się Nagra? Opracowana w 1957 r. i wprowadzona - jak wspomniałem - rok później do masowej sprzedaży „trójka” miała wiele cech znamionujących jej rywali. Podobnie jak Perfectone, oprócz rejestracji dźwięku na taśmie magnetycznej o szerokości jednej czwartej cala (ok. 6,5 milimetra), oferowała także możliwość jego synchronizacji z obrazem dzięki sygnałowi generowanemu przez zewnętrzny rezonator kwarcowy. Ważyła ponad $6 \mathrm{~kg}$ (nieco mniej niż Perfectone), co w połączeniu z wymiarami ok. $30 \mathrm{~cm}$ na $23 \mathrm{~cm}$ na $10 \mathrm{~cm}$ sprawiało, że można ją było z łatwością nosić na pasku zawieszonym na ramieniu. Co istotne, Nagra umożliwiała pracę nawet z trzema mikrofonami jednocześnie, miała panel służący do obsługi prostych funkcji mikserskich, wyjścia umożliwiające podpięcie odpowiednich urządzeń peryferyjnych, a także regulowaną szybkość przesuwu taśmy, dostosowywaną do typu kamery. O ile w twórczości dokumentalnej wykorzystywano przeważnie kamery $16 \mathrm{~mm}$, a dźwięk nagrywano z prędkością 7,5 cala na sekundę, o tyle w przypadku filmów fabularnych, realizowanych przy użyciu kamery $35 \mathrm{~mm}$, prędkość ta była dwa razy większa, a zasięg rejestrowanych częstotliwości wynosił od $20 \mathrm{~Hz}$ do $18 \mathrm{kHz}$. Porównując parametry techniczne obu najpopularniejszych europejskich systemów, Barry Salt pisał: stworzona w Szwajcarii przez Kudelskiego Nagra III odniosła większy sukces, pod koniec lat 60. stajac się zdecydowanie najczęściej wykorzystywanym sprzętem do nagrywania dźwięku na potrzeby kina na całym świecie ${ }^{12}$.

Dlaczego tak się stało? Zdecydowało o tym zapewne kilka czynników, ale najważniejszym i podkreślanym w niemal wszystkich omówieniach oraz relacjach dźwiękowców była niezawodność. Sprzęt był nie tylko lekki, ale też odporny na wstrząsy, mógł więc swobodnie zwisać z paska na ramieniu dźwiękowca, nawet pozostającego w ruchu, bez obawy o utratę jakości dźwięku czy przerwanie na- 
grywania. W tym duchu wypowiadał się choćby Les Lazarowitz, nominowany do Oscara za dźwięk do filmów Wściekły byk (Raging Bull, reż. Martin Scorsese, 1980) oraz Tootsie (reż. Sydney Pollack, 1982). Zapytany o przyczynę wieloletniej dominacji Nagry w branży filmowej odpowiedział: Niezawodność. Kiedy pracujesz nad filmem, potrzebujesz czegoś, na czym możesz polegać i co po prostu dobrze wykona swoja robotę. Nie chcesz martwić się o sprzęt, bo masz wystarczająco dużo innych zmartwień. Ostatecznie przecież cała twoja praca sprowadza się do kawałka ćwierćcalowej taśmy za siedem dolarów. Urządzenie, które to zarejestruje, musi być nie do zdarcia. (...) Ta maszyna jest zrobiona jak zegarek Rolexa. Kiedy na nia patrzysz, widzisz perfekcje. Stefan Kudelski, który zaprojektował Nagre, jest geniuszem. Stworzyt urzadzenie wyposażone w mechaniczne i elektroniczne bezpieczniki, backupy i wskaźniki pokazujace, kiedy coś zaczyna się psuć. To wytrzymała i solidna część wyposażenia, która może działać w kótko. Zawsze staram się mieć ze soba taki niezawodny, sprawdzony sprzęt ${ }^{13}$.

\section{Nowa fala dźwięku}

Znaczenie Nagry oraz innych wynalazków powstałych na przełomie lat 50. i 60. nie sprowadzało się jednak wyłącznie do kwestii technicznych czy logistycznych. Pojawienie się przenośnych magnetofonów oraz postęp w innych dziedzinach technologii filmowej, którego efektem były m.in. lżejsze, odpowiednio ciche i mobilne kamery (dla twórców filmów dokumentalnych lub fabularnych korzystających z metod dokumentu kluczowe były zwłaszcza francuski Eclair NPR oraz niemiecki Arriflex BL), czulsza taśma, znacznie doskonalsze i dyskretniejsze mikrofony kierunkowe czy cichszy i wymagający mniej zasilania sprzęt oświetleniowy, wpływały także na sposób myślenia o metodach realizacyjnych i związanych z nimi założeniach estetycznych, a nawet filozoficznych. Mirosław Przylipiak dość dokładnie rekonstruuje wspomniane przemiany technologiczne oraz powstający wokół nich dyskurs, zauważając: Konsekwencją owego postepu był swoisty determinizm technologiczny, to jest przeświadczenie o decydujacym wptywie technologii na estetyke, ontologię i etyke przekazu filmowego. (...) Jak to w późniejszym okresie ująt jeden z krytyków ruchu, mówiono o „uczciwości, prywatności, a nade wszystko obiektywizmie, jakby te stare koncepty estetyczne wynaleziono wraz z magnetofonem Nagra"14.

Idee te stanowiły jeden z fundamentów narastającej w latach 60. tendencji odchodzenia od wykoncypowanej, kontrolowanej estetyki charakterystycznej dla kina klasycznego na rzecz większej spontaniczności, dopuszczającej także (a często nawet celowo wykorzystującej) pozorne niedoskonałości czy niezręczności realizacyjne, objawiające się w fakturze obrazu, inscenizacji, montażu bądź kadrowaniu. Kamieniami milowymi tego rozwoju były wspomniane już nurty - od włoskiego neorealizmu, przez nowe tendencje dokumentalne końca lat 50., po francuską Nową Falę. Szybko dołączyły do nich kolejne nowofalowe ruchy na całym świecie, a wreszcie także kino amerykańskie - w wydaniu bardziej niezależnym (np. Johna Cassavetesa) lub też spod znaku kontestacji i Nowego Hollywoodu (od Dennisa Hoppera, przez wczesne filmy Francisa Forda Coppoli i Briana De Palmy, po Roberta Altmana). Jak już dowodziłem wcześniej, początkowo rewolucja ta nie obejmowała dźwięku, ale to także zaczęło się zmieniać właśnie na początku lat 60. Przełom ten znakomicie podsumowuje Jay Beck w książce o in- 
nowacjach w podejściu do kreowania dźwięku w amerykańskim kinie lat 70.: Przemiany dźwięku filmowego były wyraźnie opóźnione względem dokonujących się w latach 60. zmian obrazowania, obejmujacych częstsze wykorzystanie bezpośredniego oświetlenia, kamery prowadzonej z ręki, obiektywów z transfokatorem, a także akceptacje pojawiajacych się na soczewce flar jako elementu estetycznego (czyli narzędzi uznawanych we wcześniejszych dekadach za sprzeczne z założeniami filmowego realizmu). Podczas gdy grube ziarno, nietypowo skadrowane ujęcia $i$ obraz o niskiej saturacji uważano za akceptowalne pod względem estetycznym, to wciąż obowiązujacy nacisk na zrozumiałość zapisanych w scenariuszu linii dialogowych oznaczał, że praktycznie wszystkie one musiały być dobrze styszalne i nagrywane z bliska. Jednak wraz z wprowadzeniem w latach 60. takich technologii jak lekki magnetofon Nagra, mniejsze mikrofony kierunkowe z przekaźnikami radiowymi, korektory graficzne oraz wielościeżkowe konsole do montażu dźwięku mogły pojawić się nowe koncepcje i sposoby wykorzystania dźwięku. Oczywiście nie stało się to w jednej chwili, a wiele spośród wprowadzanych nowości było uzależnionych od istniejących reżimów audiowizualnych (np. gdy mikrofony kierunkowe wykorzystywane były po prostu do uzyskania "czystego" dialogu z większej odległości), ale ewolucja w dziedzinie technologii pozwoliła niektórym filmowcom wykorzystać dźwięk bardziej twórczo ${ }^{15}$.

Po spektakularnym sukcesie Czarnego Orfeusza z koncepcji przenośnego dźwięku oraz samej Nagry zaczęli korzystać w pierwszej kolejności filmowcy dążący do autentyzmu, a czasem wręcz posługujący się metodami paradokumentalnymi. W kręgu Nowej Fali pionierem wykorzystywania dźwięków „setkowych” był Claude Chabrol, który pracował tak już przy Pięknym Serge'u (Le beau Serge, 1958) oraz Kuzynach (Les cousins, 1959). Wkrótce dołączył do niego Godard, który począwszy od trzeciego filmu - Kobieta jest kobieta (Une femme est une femme, 1961) - łączył dźwięki z planu z tymi nagranymi w studiu, zrywając z obowiązującą zasadą spójności brzmieniowej. Słynący z rygorystycznych metod realizacyjnych Jean-Marie Straub i Danièle Huillet w celu osiągnięcia większego realizmu nalegali nawet na umieszczanie mikrofonu bezpośrednio nad kamera, aby jak najbardziej zbliżyć punkt widzenia i słyszenia widza ${ }^{16}$. Także Peter Brook, starający się uzyskać bardziej surowy, naturalistyczny efekt, korzystał z Nagry przy realizacji Władcy much (Lord of the Flies, 1963). Choć film ukazał się w roku 1963, to prace nad nim rozpoczęły się już trzy lata wcześniej, a Brook używał w ich trakcie prototypowej jeszcze wersji nowego systemu synchronizacji dźwięku z obrazem, który w 1962 r. został wprowadzony do powszechnego użytku jako Neopilot.

W tym pierwszym okresie szczególnie efektywny i chętnie był wykorzystywany tzw. zestaw Eclair-Nagra, czyli połączenie stosunkowo lekkiej, poręcznej kamery Eclair NPR z magnetofonem opatentowanym przez Kudelskiego. Kombinację tę spopularyzowali filmowcy z kręgu cinéma-vérité, ale szybko stała się ona standardem telewizyjnym. Taki zestaw wykorzystywał np. Michael Wadleigh, realizując swoje filmy muzyczne, w tym najsłynniejszy - Woodstock (1969). Także album muzyczny dokumentujący to wydarzenie pokoleniowe zawiera materiały zarejestrowane za pomocą Nagry III $^{17}$. Do obsługi tego zestawu wystarczyły zaledwie dwie osoby (operator kamery oraz dźwiękowiec z magnetofonem przewieszonym przez ramię oraz mikrofonem w dłoni), dzięki czemu w razie potrzeby ekipa zdjęciowa mogła zostać ograniczona do minimum. Często w ten właśnie sposob kręcił filmy Éric Rohmer, który Opowieść letnia (Conte d'été, 1996) zrealizował na publicznej plaży, tłumacząc ciekawskim wczasowiczom, że robi reportaż 
dla kanadyjskiej telewizji. Jako że cała ekipa składała się z trzech osób i niepozornego sprzętu, więc tłumaczenie brzmiało wiarygodnie.

Prawdopodobnie najlepiej ów paradokumentalny styl audiowizualny i sposób produkcji nie tylko zastosował, ale także sportretował Haskell Wexler w filmie Chłodnym okiem (Medium Cool, 1969). Twórca umiejętnie wykorzystał właściwie wszystkie narzędzia dostępne dla nowoczesnego filmowca, takie jak: zoom, długie obiektywy, prowadzona z ręki, lekka kamera Eclair czy pozwalająca kręcić przy naturalnym świetle, czuła kolorowa taśma Eastmana. To dzięki nim możliwa była realizacja zdjęć ulicznych, także w trakcie zamieszek, które towarzyszyły konwencji Partii Demokratycznej w Chicago w 1968 r. Jednocześnie - w autotematycznym geście - Wexler obnaża swój warsztat, protagonistą filmu czyniąc dziennikarza lokalnej stacji telewizyjnej, który rejestruje wydarzenia. W pierwszej scenie obserwujemy, jak wraz z partnerem dociera on - jeszcze przed policją czy pogotowiem - na miejsce śmiertelnego wypadku drogowego. Korzystając z okazji do zdobycia "mocnego", ekskluzywnego materiału, obaj nagrywają roztrzaskane auto i zakrwawione ofiary. Przyglądając się temu, możemy dostrzec kamerę Eclair NPR oraz rejestrującą na bieżąco dźwięk Nagrę III.

Zresztą o zaletach tego ostatniego sprzętu Wexler przekonał się już kilka lat wcześniej. Według wspomnień jego syna, skądinąd znakomitego dźwiękowca, pierwszym hollywoodzkim filmem, w którym wykorzystano Nagrę, był Ten najlepszy (The Best Man, 1964) Franka J. Schaffnera. Wexler pracował przy nim jako operator, zaś autorem dźwięku był wspominany już Jack Solomon, który prawdopodobnie wtedy wyrobił sobie opinię o sprzęcie Kudelskiego jako rewolucji branżowej. Co ciekawe, Jeff Wexler ówczesne spotkania z dźwiękowcami czy innymi pracownikami opisuje jako przepełnione podziwem dla samej techniki, choć podziw ten był przeważnie komentowany stwierdzeniem, że nie ma ona szans przyjąć się w mainstreamowej produkcji dużych studiów ${ }^{18}$.

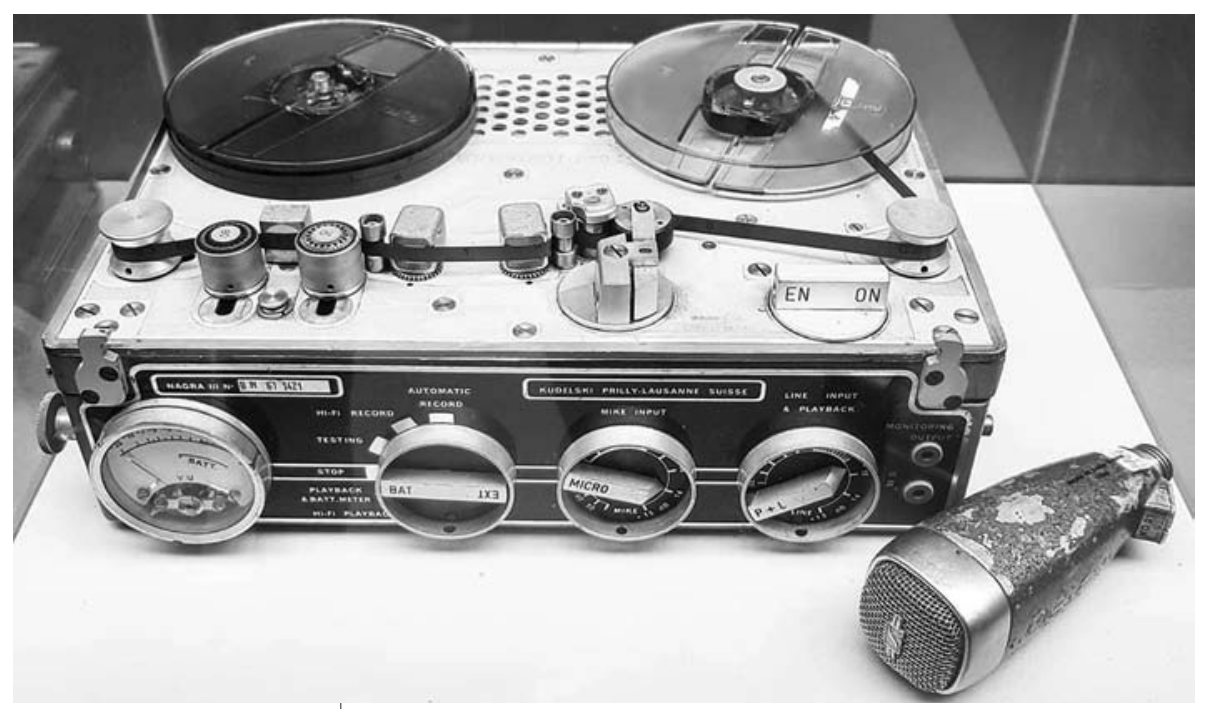

Nagra III N, kompaktowy standard rejestracji dźwięku w latach 70. (domena publiczna) 
Tymczasem w latach 70. Nagra, i w ogóle dźwięk zgrywany na planie, była już hollywoodzkim standardem, szczególnie chętnie i kreatywnie wykorzystywanym zwłaszcza przez reżyserów współtworzących fenomen tzw. Nowego Hollywood - Martina Scorsese, Francisa Forda Coppolę czy George'a Lucasa. Analizując ten fenomen, Jay Beck zwraca szczególną uwagę na rolę inżyniera dźwięku Waltera Murcha, który przy użyciu Nagry rejestrował, a potem sam obrabiał i montował dźwięk do takich filmów jak Ludzie z deszczu (The Rain People, 1969) Coppoli czy Amerykańskiego graffiti (American Graffiti, 1973) Lucasa ${ }^{19}$. Jak podsumowuje Beck: Podstawowym estetycznym efektem pojawienia się przenośnego i zsynchronizowanego z kamera sprzętu do nagrywania, takiego jak Nagra III, było wyzwolenie dźwięku z ograniczeń obrazu. W czasie zdjęć plenerowych ekipa realizująca dźwięk nie była już przywiązana do kamery. Zamiast tego dźwiękowcy mogli eksperymentować z ruchem mikrofonu, umiejscowieniem sprzętu do nagrywania i ogólnie oddzieleniem dźwięku od obrazu ${ }^{20}$.

Reżyserem pochodzącym z tego grona, który stworzył niewątpliwie najbardziej wyrazisty styl audialny, jest Robert Altman. Jego filmy z połowy lat 70. słynęły ze złożonych, polifonicznych ścieżek dźwiękowych, na których często nakładają się na siebie różne fragmenty dialogów oraz odgłosy otoczenia. Zwłaszcza w dziełach takich jak Nashville (1975) czy Wesele (A Wedding, 1978) metoda ta kontrapunktycznie oddaje wielość postaci oraz przecinających się ścieżek narracyjnych. Aby osiągnąć ten efekt, począwszy od Kalifornijskiego pokera (California Split, 1974), Altman za pomocą ustawionych w różnych miejscach mikrofonów nagrywał równocześnie kilka ścieżek, które potem starannie montował, łącząc je niejednokrotnie z dźwiękami ze studia. Wprawdzie nie korzystał w tym celu ze sprzętu Kudelskiego, tylko z 8-ścieżkowego urządzenia Stevens Electronics, ale już jego naśladowcy często tak. Jak tłumaczy Barry Salt: Altmanowskie metody w najbardziej rozbudowanej formie nie zostały przez nikogo podchwycone, cześsiowo także dlatego, że jakość nagrań z mikroportów znajdujacych się przy ciałach aktorów nie spetniała najwyższych standardów. Niemniej dźwiękowcy zaczęli coraz częściej nagrywać za pomoca kilku mikrofonów jednocześnie, często wykorzystując do tego celu niezależne dwie ścieżki stereo w Nagrze ${ }^{21}$. Tę ostatnią praktykę umożliwiła w latach 70. wyposażona w opcję nagrywania stereo Nagra IV-S. Model wprowadzony został na rynek w roku 1971, ale ze względu na nieco większe gabaryty i cenę nigdy na dobre nie zastąpił "trójki”.

Z czasem jednak okazało się, że możliwości, jakie daje lekka i poręczna Nagra, nie ograniczają się do łatwiejszego nagrywania dźwięku na planie, a rezultaty jej użycia niekoniecznie muszą wzmagać wrażenie realizmu. Także dźwiękowcy poszukujący materiałów z innych źródeł lub pracujący z dźwiękiem przetworzonym mogli skorzystać z mobilności, jaką zapewniają przenośne magnetofony, w celu swobodniejszego poszukiwania właściwych brzmień i tym samym uniezależnienia się od wspomnianych bibliotek lub pracujących w studiu imitatorów dźwięku. Ostatecznie wszak wszystkie dźwięki słyszane w kinie przed epoką cyfrową musiały mieć jakieś źródło rzeczywiste - także te najbardziej fantastyczne. Znamiennego przykładu dostarczają Gwiezdne wojny (Star Wars, reż. George Lucas, 1977), które w historii dźwięku filmowego zapisały się przede wszystkim jako pierwszy film dystrybuowany w systemie Dolby Stereo. Za audialny charakter sagi Lucasa - przynajmniej częściowo - odpowiadała Nagra, dzięki której autor dźwięku, Ben Burtt, mógł znacznie swobodniej poszukiwać od- 
głosów stanowiących podstawę późniejszych przetworzeń i eksperymentów. W ten sposób opisuje to William Whittington: Korzystajac z magnetofonu Nagra, Burtt był w stanie zbierać surowe efekty dźwiękowe do "Gwiezdnych wojen" w catej Kalifornii. Nagranie autostrady w Los Angeles przez pofałdowana tubę zamienito się później w brzmienie ścigaczy, a dźwięk zepsutej klimatyzacji zostat zarejestrowany i odpowiednio przetworzony, stając się pomrukiem statku w sekwencji otwierajacej pierwsza część trylogii. Mobilność i kreatywność Burtta umożlizwiła mu pozyskanie nagrań z najróżniejszych miejsc-od ogrodów zoologicznych po lotniska ${ }^{22}$.

Znacznie skromniejszy, jeśli chodzi o skalę, ale podobny w swojej istocie proces poszukiwania odpowiednich dźwięków możemy zobaczyć w sfikcjonalizowanej wersji w Wybuchu (Blow Out, 1981) Briana De Palmy. Jego protagonista jest Jack - dźwiękowiec, którego zadaniem jest znalezienie odpowiednich odgłosów, w tym idealnego krzyku, do slashera klasy B. W jednej z pierwszych scen wybiera się on do parku wyposażony $w$ niewielki magnetofon - $\mathrm{w}$ zbliżeniu widać wyraźnie oznaczenia modelu Nagra III - za pomocą którego (w połączeniu z mikrofonem kierunkowym) nagrywa odgłosy spacerującej pary, pohukiwań sowy, a wreszcie także podejrzanego wypadku, który staje się początkiem właściwej intrygi. Gdy bohater odsłuchuje później zebrane materiały, rekonstruując przebieg wydarzeń, kamera w zbliżeniu, w niemalże fetyszystyczny sposób, pokazuje prace magnetofonu - przeskakujące mechanizmy, przesuwającą się taśmę i chromowane powierzchnie. Nagra pojawia się zresztą w tym filmie kilka razy, migając w tle pracowni głównego bohatera, a także w scenie, gdy jest on podsłuchiwany i kiedy widzimy, że jego rozmowa telefoniczna zapisywana jest na ukrytej w piwnicy miniaturowej Nagrze SN.

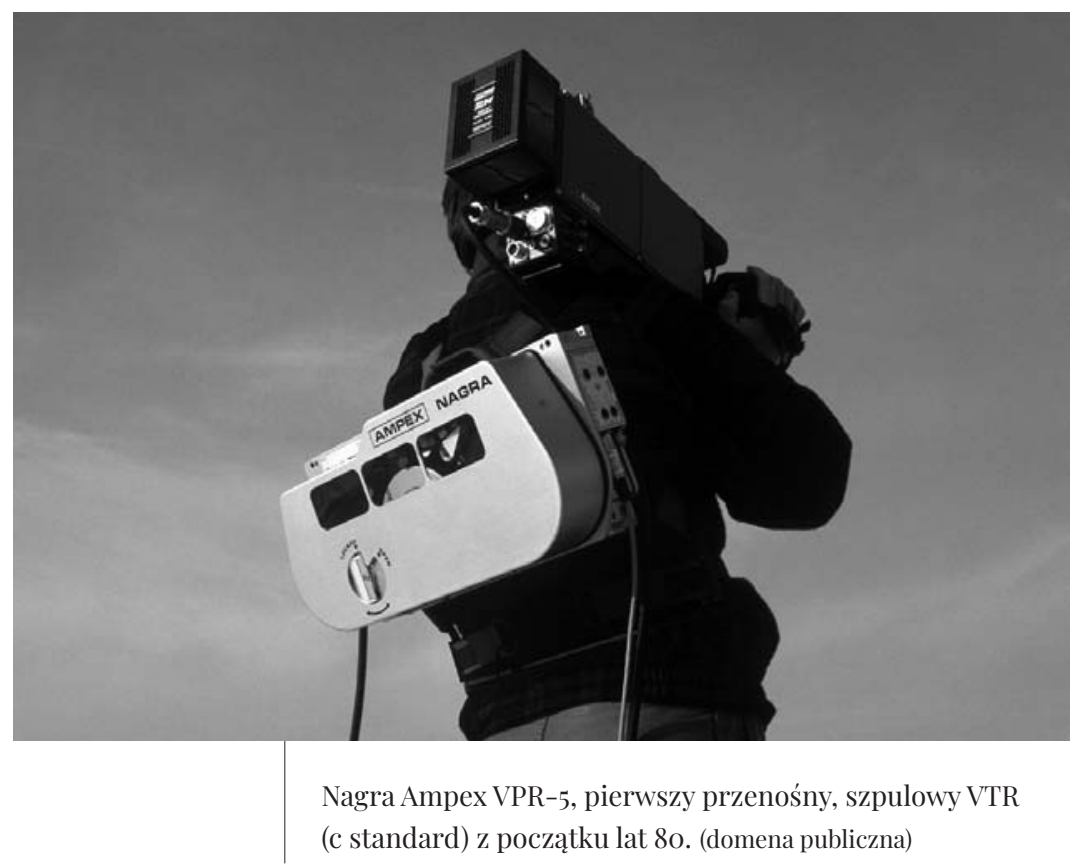


Jak pokazuje ten przypadek (a także wspomniane wcześniej Chłodnym okiem), wynalazek Stefana Kudelskiego nie tylko umożliwił stworzenie tysięcy filmów, programów telewizyjnych czy reportaży, lecz także był tak lubiany i powszechny wśród ekip filmowych, że niejednokrotnie pojawiał się po drugiej stronie kamery. Czasem jako zwykły rekwizyt, jak w Egzorcyście (The Exorcist, 1973) Williama Friedkina, w którym dobywające się z gardła opętanej dziewczynki demoniczne głosy zostają uwiecznione właśnie na sprzęcie Kudelskiego; innym razem jako kluczowy element fabuły - tak jest nie tylko w Wybuchu, ale też w Divie (1981) Jeana-Jacques'a Beineixa, której główny bohater Jules obnosi się ze swoją Nagra, umożliwiającą mu uchwycenie pięknego głosu tytułowego obiektu westchnień.

\section{Cyfrowe zapomnienie?}

Tak gigantyczny wpływ na branżę filmową nie pozostał naturalnie niezauważony. W podzięce za swoje wynalazki Stefan Kudelski otrzymał niezliczone laury, w tym między innymi dwie nagrody Emmy, był też honorowym członkiem SMPTE (Society of Motion Picture and Television Engineers). Najcenniejsze były dla niego zapewne cztery nagrody Amerykańskiej Akademii Filmowej-dwa tzw. małe Oscary, czyli nagrody naukowo-techniczne (przyznane w roku 1965 oraz 1977), a także dwa „właściwe” - wręczoną mu w 1978 r. za model Nagra 4.2 L Award of Merit oraz honorową Nagrodę im. Gordona E. Sawyera za całościowy wkład w rozwój kinematografii - w roku 1990.

Moment przyznania tego ostatniego wyróżnienia może wydawać się symboliczny. Po tym jak Nagra stopniowo przeniknęła do kinematografii w latach 60., przez kolejne dwie dekady niezmiennie utrzymywała reputację złotego standardu w swojej dziedzinie. W tym czasie urządzenie przechodziło oczywiście ciągłe zmiany - jego twórcy proponowali mniej lub bardziej trafione udoskonalenia techniczne i starali się nadążać za panującymi trendami ${ }^{23}$. Jednocześnie w latach 80 . zaczęły się pojawiać pierwsze zwiastuny zjawiska, które już wkrótce miało ponownie odmienić całą branżę - rewolucji cyfrowej. Branża muzyczna już wówczas promowała nowy nośnik dystrybucji, jakim była płyta $C D$, zaś w kinematografii z cyfrowym dźwiękiem eksperymentował Steven Spielberg podczas pracy nad Indiana Jonesem i Światynia Zagłady (Indiana Jones and the Temple of Doom, 1984). Stosowny sprzęt był jednak drogi i nieporęczny, a efekty pracy z nim niezadowalające, gdyż dźwięk i tak musiał zostać przekonwertowany do tradycyjnego, analogowego formatu na potrzeby dystrybucji kopii kinowych. Jrdnak z technologii cyfrowej coraz chętniej korzystano w postprodukcji, na etapie montażu dźwięku i generowania dodatkowych efektów. Wkrótce cyfrowy dźwięk pojawił się na etapie projekcji - w 1990 r. firmy Kodak i Optical Radiation Corporation opracowały system Cinema Digital Sound, który jeszcze w tym samym roku został zastosowany w filmach Dick Tracy (reż. Warren Beatty, 1990) oraz Szybki jak błyskawica (Days of Thunder, reż. Tony Scott, 1990), zaś ostatecznie standardem okazał się nowszy system Dolby.

W tym samym więc momencie, w którym Stefan Kudelski odbierał Oscara za całokształt pracy, dni chwały jego najważniejszego wynalazku dobiegały końca. Wprawdzie na początku dekady dźwięk na planie wciąż nagrywano głównie Nagrą (najczęściej modelem IV), ale na rynku pojawiały się już magnetofony cyf- 
rowe, posługujące się formatem DAT (Digital Audio Tape) i zapisujące dźwięk na niewielkich kasetach. Ich pierwsze modele nie miały jeszcze markerów czasowych pozwalających na synchronizację z kamera, szybko jednak pojawiły się i takie były to japoński Fostex PD-2 i stworzony przez firmę Stellavox model Stelladat. Firma Kudelskiego włączyła się do tego wyścigu, w 1992 r. wypuszczając na rynek cyfrowy model Nagra D. Nie miał on już jednak zalet wcześniejszych produktów tej marki - był ciężki (ważył blisko 20 kg), znacznie większy i kosztowny, bo wyceniany na 29 tys. dolarów, czyli ponad dwukrotnie więcej niż sprzęt konkurencji. Co więcej, zamiast przyjętego już systemu DAT operował on własnym formatem zapisu. Choć Nagra D miała też swoje plusy - mogła nagrywać cztery ścieżki (konkurencyjne urządzenia - dwie), a także rejestrowała dźwięk 20-bitowy (DAT - 16bitowy), co zapewniało lepszą jakość i większe możliwości obróbki nagrań ${ }^{24}$. Jeśli dodamy do tego wszystkiego fakt, że produkcja filmowa - zwłaszcza hollywoodzka - zaczęła w latach 90. przenosić się z powrotem do studia, gdzie tworzono coraz bardziej fantastyczne blockbustery i chętniej korzystano ze sprzętu stacjonarnego, to okaże się, że w tej dekadzie Nagra musiała zejść ze sceny. Kolejne próby powrotu do przejęcia wiodącej roli w branży nie powiodły się, choć magnetofony serii zapoczątkowanej przez Kudelskiego nigdy zupełnie nie wyszły z użytku. Jego przedsiębiorstwo weszło też na inne rynki i już od lat 70. opracowywało technologie na użytek branży morskiej oraz lotniczej, a współcześnie produkując między innymi sprzęt hi-fi oraz dekodery cyfrowe. Stefan Kudelski zmarł w 2013 r., a jego firma jest dzisiaj zarządzana przez syna Andrzeja.

Rola, jaką polski wynalazca odegrał w branży filmowej, wciąż nie została dostatecznie opisana. Niniejszy artykuł miał na celu jedynie przybliżenie kontekstu, w jakim Nagra pojawiła się w historii kina, pomagając wypracować nowe metody rejestracji synchronicznej ścieżki dźwiękowej i towarzyszące temu kody estetyczne. Miała ona zastosowanie w kinie dokumentalnym oraz korzystającym z jego konwencji realistycznym kinie fabularnym lat 60. i 70.; zapewniała realizacyjną elastyczność i niezawodność ekipom pracującym w plenerze i trudnych warunkach, ułatwiła też poszukiwania nowych dźwięków wykorzystywanych w kinie kreacyjnym spod znaku Nowej Przygody. Moja refleksja to jednak zaledwie wprowadzenie i zachęta do poważniejszych badań, które obejmowałyby zarówno rozważania technologiczne, związane z konstrukcyjną stroną sprzętu filmowego, jak też produkcyjne i społeczne, odnoszące się do organizacji pracy oraz branżowych praktyk na tym obszarze, a wreszcie estetyczne, skupione na bezpośrednim związku technologii z ekranowymi artefaktami. Dopiero z ich połączenia mógłby wyłonić się bardziej rozbudowany obraz fascynującego zjawiska, jakim była Nagra.

${ }^{1}$ R. Altman, The Evolution of Sound Technology, w: Film Sound: Theory and Practice, red. E. Weis, J. Belton, Columbia University Press, New York 1985, s. 44.

${ }^{2} \mathrm{Na}$ temat roli dźwięku w kinie niemym i wczesnych eksperymentów w kinie dźwiękowym, zob. m.in. R. Abel, R. Altman (red.), The Sounds of Early Cinema, Indiana University Press, Bloomington - Indianapolis 2001;
D. Gomery, The Coming of Sound: A History, Routledge, New York - London 2005; D. Neumeyer, J. Buhler, R. Deemer, Hearing the Movies: Music and Sound in Film History, Oxford University Press, New York Oxford 2010, s. 247-277; I. Sowińska, Przełom dźwiękowy, w: Historia kina. Kino klasyczne, red. T. Lubelski, I. Sowińska, R. Syska, Universitas, Kraków 2011, s. 19-32. 
${ }^{3}$ M. A. Macura, Nagrastory. Stefan Kudelski, jego cztery Oskary i... inne opowieści rodzinne, Mamiko, Nowa Ruda 2019, s. 188.

${ }^{4}$ Tamże, s. 186.

${ }^{5}$ Zob. J. Belton, 1950s Magnetic Sound: The Frozen Revolution, w: Sound Theory, Sound Practice, red. R. Altman, Routledge, New York London 1992, s. 154-170.

${ }^{6}$ D. Neumeyer, J. Buhler, R. Deemer, dz. cyt., s. 363 .

${ }^{7}$ D. Bordwell, K. Thompson, Film History: An Introduction, McGraw Hill, New York 2010, s. 331.

${ }^{8}$ G. Nowell-Smith, Making Waves: New Cinemas of the 1960s, Continuum, New York London 2008, s. 69-70.

${ }_{9}^{9}$ M. Przylipiak, Kino bezpośrednie. 1960-1963, słowo/obraz terytoria, Gdańsk 2007, s. 7-8.

${ }^{10}$ V. LoBrutto, Sound-on-film: Interviews with Creators of Film Sound, Praeger, Westport 1994, s. 8.

${ }^{11}$ M. A. Macura, dz. cyt., s. 191.

${ }^{12}$ B. Salt, Film Style and Technology: History and Analysis (wyd. 3), Starword, London 2009, s. 299.

${ }^{13}$ V. LoBrutto, dz. cyt., s. 126-127.

${ }^{14}$ M. Przylipiak, dz. cyt., s. 8.

${ }^{15}$ J. Beck, Designing Sound: Audiovisual Aesthetics in 1970s American Cinema, Rutgers University Press, New Brunswick - London 2016, s. 4.

${ }^{16}$ G. Nowell-Smith, dz. cyt., s. 214.
${ }_{17}$ Zob. L. Palmer, The Portable Recording Studio: Documentary Filmmaking and Live Album Recording, 1967-1969, ,Journal of the International Association for the Study of Popular Music" 2016, vol. 6, no 2, s. 49-69.

18 Zob. wypowiedzi Jeffa Wexlera na branżowym forum poświęconym pracy dźwiękowców dostępne pod adresem: https://jwsoundgroup.net/index.php?/topic/23814-nagrastories-sound-men-won $\%$ E2\%80\%99t-evertell/ (dostęp: 15.03.2021). Forum to jest zresztą znakomitą kopalnią wiedzy i anegdot na temat Nagry - w osobnym wątku dźwiękowcy wymieniają się informacjami, poglądami oraz wspomnieniami z pracy z urządzeniem Kudelskiego.

${ }^{19}$ Zob. J. Beck, dz. cyt., s. 88, 156.

${ }^{20}$ Tamże, s. 30.

${ }^{21}$ B. Salt, dz. cyt., s. 319.

${ }^{22}$ W. Whittington, Sound Design in New Hollywood Cinema, w: Sound and Music in Film and Visual Media: A Critical Overview, red. G. Harper, Bloomsbury, New York - London 2009, s. 563.

${ }^{23}$ Techniczne szczegóły kolejnych modeli Nagry znakomicie opisuje Scott D. Smith w tekście napisanym w hołdzie Kudelskiemu po jego śmierci. Zob. S. D. Smith, A Tribute to Stefan Kudelski and the Nagra Recorder, "695 Quarterly" 2013, vol. 5, no 2, s. 24-30.

${ }^{24}$ Zob. B. Salt, dz. cyt., s. 355.

\section{Milosz Stelmach}

\section{Bibliografia}

Abel, R., Altman, R. (red.) (2001). The Sounds of Early Cinema. Bloomington - Indianapolis: Indiana University Press.

Altman, R. (1985). The Evolution of Sound Technology. W: E. Weis, J. Belton (red.), Film Sound: Theory and Practice (ss. 44-53). New York: Columbia University Press. 
Beck, J. (2016). Designing Sound: Audiovisual Aesthetics in 1970 s American Cinema. New Brunswick - London: Rutgers University Press.

Belton, J. (1992). 1950s Magnetic Sound: The Frozen Revolution. W: R. Altman (red.), Sound Theory, Sound Practice (ss. 154-170). New York - London: Routledge.

Bordwell, D., Thompson, K. (2010). Film History: An Introduction. New York: McGraw Hill.

Gomery, D. (2005). The Coming of Sound: A History. New York - London: Routledge.

LoBrutto, V. (1994). Sound-on-film: Interviews with Creators of Film Sound. Westport: Praeger.

Macura, M. A. (2019). Nagrastory. Stefan Kudelski, jego cztery Oskary i... inne opozieśsi rodzinne. Nowa Ruda: Mamiko.

Neumeyer, D., Buhler, J., Deemer, R. (2010). Hearing the Movies: Music and Sound in Film History. New York - Oxford: Oxford University Press.

Nowell-Smith, G. (2008). Making Waves: New Cinemas of the 196os. New York - London: Continuum.

Palmer, L. (2016). The Portable Recording Studio: Documentary Filmmaking and Live Album Recording, 1967-1969. Fournal of the International Association for the Study of Popular Music, 6 (2), ss. 49-69.

Przylipiak, M. (2007). Kino bezpośrednie. 1960-1963. Gdańsk: słowo/obraz terytoria.

Salt, B. (2009). Film Style and Technology: History and Analysis (wyd. 3). London: Starword.

Smith, S. D. (2013). A Tribute to Stefan Kudelski and the Nagra Recorder. 695 2uarterly, 5 (2), Ss. 24-30.

Sowińska, I. (2011). Przełom dźwiękozy. W: T. Lubelski, I. Sowińska, R. Syska (red.), Historia kina. Kino klasyczne (t. 2, ss. 19-72). Kraków: Universitas.

Whittington, W. (2009). Sound Design in New Hollywood Cinema. W: G. Harper (red.), Sound and Music in Film and Visual Media: A Critical Overview. New York - London: Bloomsbury.

\section{Keywords:}

Nagra;

Stefan Kudelski;

film sound;

film technology;

film history;

New Hollywood

\section{Abstract}

Miłosz Stelmach

The Second Coming of Sound? Nagra Tape Recorder and the Evolution of Sound in Postclassical Cinema

The aim of this article is to present the influence exerted on cinema by Stefan Kudelski and his invention: the family of Nagra recorders. Introduced in 1958, Nagra III became especially popular among filmmakers, enabling, along with other technical breakthroughs of that time, the development of a new kind of documentary filmmaking, and later influencing feature production as well. For almost three decades, various models of Nagra recorders presented the golden standard in its field and helped shaping movements such as French New Wave and New Hollywood. It thus pla- 
yed an important part in the emergence of 'postclassical' cinema, which encompassed a new kind of cinematic realism and much more freedom in creating sound design. This important episode in the history of film technology might be instructive in understanding how technical progress might influence the culture and logistics of production but also inform strictly artistic and aesthetic choices made by filmmakers.

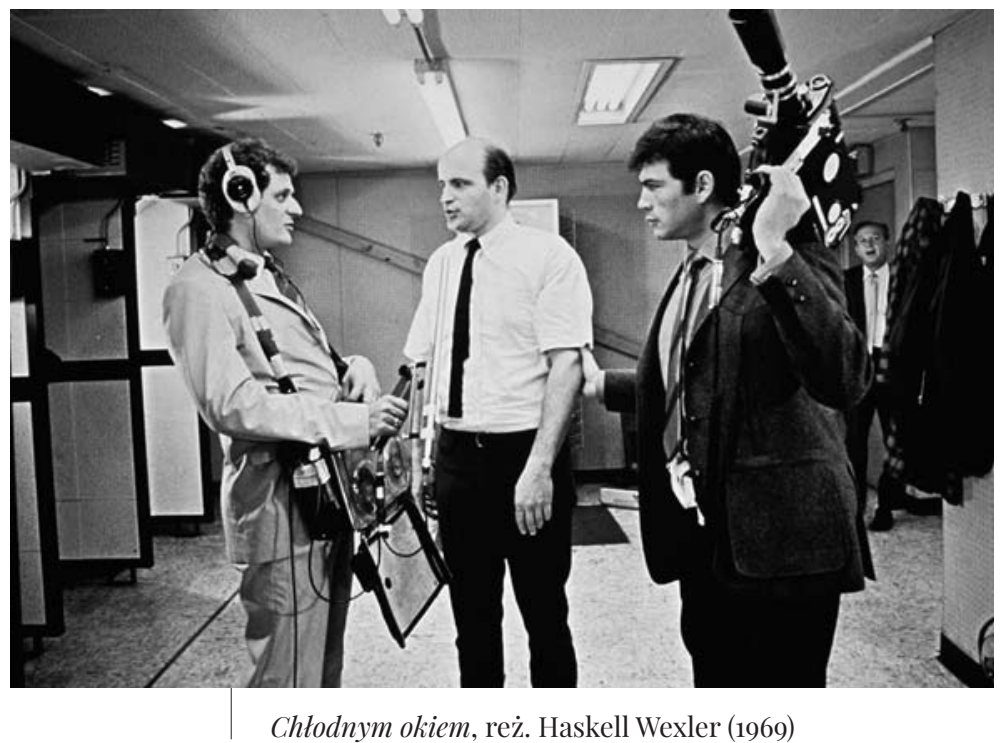

